\title{
Консервативна реабілітація опікових реконвалесцентів при реконструкції рубцевих деформацій
}

\author{
УДК 616.5-001.17:617.52-089.844
}

О. А. Жернов ${ }^{1}$, О. І. Осадча ${ }^{2}$, Р. Я. Трач ${ }^{3}$, О. О. Гузь 4

\author{
${ }^{1}$ Національна медична академія післядипломної освіти імені П. Л. Шупика МОЗ \\ України, Київ, Україна \\ ${ }^{2}$ Національний університет фізичного виховання і спорту України, Київ, Україна \\ ${ }^{3}$ КНП «Луцька міська клінічна лікарня», Луцьк, Україна \\ ${ }^{4}$ КНП «Київський міський клінічний онкологічний центр», Київ, Україна
}

\begin{abstract}
Резюме. Система заходів консервативної реабілітації хворих з рубцевими ураженнями у перед та післяопераційні періоди реконструкції деформацій включає місцеві, медикаментозні, фізіотерапевтичні, бальнеологічні засоби та методи еферентної терапії. Позитивний вплив заходів досягається за рахунок зниження рівня вмісту аутоагресивних факторів, що відображується у сприятливому клінічному перебігу процесу. Застосування системи заходів дозволяє своєчасно забезпечити сприятливі умови для компенсації загального стану реконвалесцентів та відновлення чи покращення порушених функцій уражених сегментів за об'єктивними оцінками у 1,75 раза і за оцінками пацієнтів - у 1,44 раза.

Ключові слова: опіки, хворі з рубцевими ураженнями, деформацій, наслідки опікової хвороби.
\end{abstract}

Conservative rehabilitation of burn convalescents in the reconstruction of scar deformities

O. A. Zhernov', O. I. Osadcha ${ }^{2}$, R. I. Trach ${ }^{3}$, O. A. Guz ${ }^{4}$

${ }^{1} \mathrm{PL}$ Shupyk National Medical Academy of Postgraduate Education of the Ministry of Health of Ukraine, Kyiv

${ }^{2}$ National University of Physical Education and Sport of Ukraine, Kyiv, Ukraine

${ }^{3} \mathrm{KNP}$ «Lutsk Municipal Clinical Hospital», Lutsk, Ukraine

${ }^{4}$ KNP «Kyiv Municipal Clinical Oncological Centre», Kyiv, Ukraine

Abstract. The system of measures for conservative rehabilitation of patients with cicatricial lesions during pre- and postoperative periods of deformity reconstruction includes local, medication, physiotherapeutic, balneological means and methods of efferent therapy. A positive effect of measures is achieved by reducing the level of auto-aggressive factors, which is displayed in a favorable clinical course of the process. The application of the system of measures allows timely providing favorable conditions for compensating general condition of convalescents and restoring or improving the impaired functions of the affected segments according to objective estimates by 1.75 times and according to patients estimates by 1.44 times.

Keywords: burns, patients with cicatricial lesions, deformations, consequences of a burn disease.

Постановка проблеми. Відомо, що рубцева тканина зазнає етапних змін і має певні стадії розвитку. Ці зміни виникають у зв'язку з еволюцією клітинно-мезенхімальних взаємодій в рубцях внаслідок місцевих і загальних запальних, біохімічних та імунологічних реакцій [1-3].

При опіковій хворобі в крові накопичуються циркулюючі імунні комплекси (ЦІК), внаслідок порушення природних механізмів їх виведення з організму. Це стає причиною пригнічення клітинних механізмів захисту та порушення фрункціональної активності імунокомпетентних клітин через їхнє токсичне ушкодження [4]. Накопичення аутоантитіл в організмі потерпілого з важкими опіками призводить до патології сполучної тканини, що проявляється утворенням патологіч- 
них рубців, рубцевих деформацій і контрактур $[5,6]$.

У перші місяці рубці зазнають набухання та ретракції і їхня первинна площа зменшується на 30-40\%. Подальша деретракція призводить до деякого розширення рубців й зменшення їх щільності. Лише через 10-12 міс., а в деяких випадках через кілька років рубці стабілізуються. Саме в цей період рекомендується здійснювати відновні хірургічні втручання. Проведення реконструкції рубцевих деформацій дозволяє усунути контрактуру, що призводить до наступного перерозподілу напрямків рубцевої тяги. У цей час рубці знову зазнають змін і можливе відновлення місцевих і загальних патологічних реакцій, що стають новим поштовхом до рубцеутворення у місцях післяопераційного поля та рецидиву деформації $[2,5]$. Для усунення впливу хірургічних втручань на формування рубцевих тканин можливо застосування консервативних реабілітаційних заходів. Головним завданням реабілітації $\epsilon$ своєчасне забезпечення сприятливих умов для компенсації порушених фрункцій уражених сегментів, визначення науково-обґрунтованої тактики відновного лікування [7].

Нині для зменшення місцевих запальних реакцій використовують медикаментозні, ефеерентні, фізіотерапевтичні, бальнеологічні та інші методи $[2,8]$. Однак системне застосування цих методів та визначення їх ефективності не вивчалося.

Мета дослідження - покращити результати лікування опікових реконвалесцентів при реконструкції рубцевих деформацій з використанням системи заходів консервативної реабілітації.

Матеріал та методи дослідження. За період з лютого 2017 р. по жовтень 2019 р. під спостереженням перебувало 18 хворих віком від 15 до 35 років (середній вік 19,6 років). Серед постраждалих чоловіків було 7 (38,8 \%), жінок - $11(61,2 \%)$. Хворі мали післяопікові рубцеві ураження покривних тканин шиї (5), тулуба (6), верхніх (4) та нижніх (3) кінцівок. Середній строк існування деформацій становить 8, 2 міс. Рубцеві деформації були представлені незрілою гіпертрофовоною рубцевою тканиною яскравочервоного кольору у деяких випадках - $з$ цианотичним відтінком, бугристою поверхнею, висотою 0,8-1,8 см. Пацієнти відзначали виражені неприємні відчуття, свербіж та біль. Показанням для хірургічного лікування були порушення фрункцій ураженого сегмента у вигляді початку розвитку кіфосколіотичної деформації хребта, утруднення самообслуговування та ходи, обмеження рухів грудної клітки та черевної стінки.
У передопераційний період пацієнтам здійснювали консервативне лікування, направлене на покращення кровообігу в зоні ураження, зменшення рубцеутворення, збільшення об'єму рухів у суглобах ураженої кінцівки чи її сегментах, профрілактику деформацій. Усім хворим виконували хірургічну корекцію деформацій з використанням розтягнутих клаптів 3 власним кровообігом, місцевої та комбінованої пластики. Після загоєння післяопераційних ран призначали комплексне консервативне лікування.

Використовували транссузійну терапію, спрямовану на детоксикацію і корекцію основних показників гомеостазу, яка здійснювалась за схемою гіперволемічної гемодилюції з форсованим диурезом. Об'єм трансфузійних середовищ становив 20-80 мл $\mathrm{k}^{-1}$ протягом 5 діб. Мембранний плазмафререз проводили трикратно з одноразовим забором крові від 150 (діти) до 800 мл. Для пероральної детоксикаціі застосовували кремнійорганічний сорбент «Ентеросгель» по 10-15г двічі на день.

Для зменшення аутоіммунного запалення використовували солу-медрол у вигляді інфузійної пульс-терапії в дозах 250 мг (діти до 35 кг), 500 та 1000 мг протягом 5 діб. Рекомендували антигістамінні, протизапальні, антиспастичні засоби, тканьові препарати, вітаміни.

Місцево на ділянки рубців, що підлягали подальшому хірургічному лікуванню та у післяопераційний період застосовували препарати «Каріпаїн крем» та «Каріпаїн Плюс». Перший шляхом нанесення на уражену ділянку площею 60-140 см² й ультразвукового уведення протягом 20 хв упродовж 12 днів. «Каріпаїн Плюс» наносили на рубці площею до $120 \mathrm{~cm}^{2}$ та післяопераційні рани - тривалий час втирали до повного всмоктування [9].

Призначали лікувальну фрізкультуру, масаж сегментів кінцівок, масаж трансплантатів, а також з'ємне позиціювання ураженого сегмента у положенні гіперкорекції. Рекомендували використання компресійних пов'язок та силіконових пластин, призначали санаторно-курортне лікування із застосуванням природних фракторів (морські, радонові, сірководневі ванни).

Для оцінки ефективності застосування даного методу використовували клінічні та лабораторні дослідження.

Для оцінки клінічних ознак рубцевих уражень застосовували модифріковану шкалу оцінки рубців, яка складається 3 двох чисельних частин - шкали пацієнта (батьків) та шкали спостерігача. Шкала пацієнта (батьків) залежно від ступеня вираженості складалася з таких ознак, 
як біль та свербіж у рубцях (0-3 бали), їх колір (0-3 бали), товщина (0-3 бали) та пластичність (0-4 бали). Шкала спостерігача включала визначення пігментації (0-3 бали), кольору (0-3 бали), висоти (0-4 бали), рухливості (0-5 балів) та площі рубця (0-4 бали).

Пігментацію, рухливість та колір рубця оцінювали клінічно шляхом спостереження за ним. Висоту рубця визначали шляхом вимірювання штангенциркулем. Площу рубця вимірювали за допомогою додатка до айфронів LesionMeter версія 1.2, що використовується для виміру площі десректів шкіри. Ступінь контрактури визначали за класифрікацією [7], а обсяг рухів - за допомогою гоніометра.

Ознаки, що визначались лікарем і хворим, оцінювали у балах. Бальну оцінку клінічних ознак проводили під час первинного огляду та після завершення курсу стаціонарного консервативного лікування. Ступінь ефрективності проведеного лікування визначали за змінами суми балів. Зменшення значень свідчило про регрес рубця, а їх збільшення означало продовження зростання рубця.

Лабораторними критеріями ефективності служили такі показники:

- вміст лімфоцитів i еозинофрілів у перифреричній крові хворих з рубцевими десормаціями;

- активність лімфоццитів в аутоімунних реакціях;

- вплив аутологічної сироватки та її срракцій на показники активності лімфоцитів в аутоімунних реакціях;

- вміст циркулюючих імунних комплексів (ЦІК) та криоглобулінів.

Для статистичного аналізу було використано програму SPSS v. 17.0. Всі визначені параметри результатів лослідження вивчали за допомогою непараметричних тестів Крускала-Уолліса та Манна-Уітні. Значення виражалися як середня \pm стандартна похибка середнього значення. Статистично значима різниця між значеннями $\mathrm{p}<0,05$.

Результати дослідження та їх обговорення. Аналіз результатів лікування хворих 3 рубцевими деформаціями 3 використанням реабілітаційних заходів показав позитивну динаміку клінічних ознак рубцевої тканини як за об'єктивними (пігментація, висота, ширина, колір, рухливість), так і суб'єктивними (біль, свербіж, товщина, пластичність) оцінками. Середня величина бальної об'єктивної оцінки вихідного стану рубцевої тканини становила 14 балів (від 8 до 18) та за оцінкою пацієнтів - 13 балів (від 7 до 16). Після проведеного консервативного лі-
ТАБЛИЦЯ 1 - Зміна показників крові у хворих з рубцевими деформаціями при застосуванні програми лікування $(\mathrm{n}=18)$

\begin{tabular}{|l|c|c|c|}
\hline \multicolumn{1}{|c|}{ Показники } & $\begin{array}{c}\text { До } \\
\text { лікування }\end{array}$ & $\begin{array}{c}\text { Після } \\
\text { лікування }\end{array}$ & $\begin{array}{c}\text { Здорові } \\
\text { особи }\end{array}$ \\
\hline Лейкоцити, × $10^{9} / л$ & $9,3 \pm 0,4^{*}$ & $7,4 \pm 0,3$ & $5,7 \pm 0,3$ \\
\hline Еозинофріли, \% & $3,8 \pm 0,2^{*}$ & $2,1 \pm 0,2^{* *}$ & $1,3 \pm 0,1$ \\
\hline Моноцити, \% & $3,7 \pm 0,3^{*}$ & $3,9 \pm 0,2^{*}$ & $5,3 \pm 0,2$ \\
\hline Лімфоцити, \% & $46,7 \pm 2,1^{*}$ & $38,4 \pm 2,4^{* *}$ & $30,1 \pm 0,8$ \\
\hline
\end{tabular}

* $p<0,05$ - вірогідність відмінностей відносно показників здорових осіб, ${ }^{* *} p<0,05$ - вірогідність відмінностей відносно вихідних показників.

кування середня величина бальної об'єктивної оцінки була 8 балів (від 5 до 15) та за оцінкою пацієнтів - 9 (від 5 до 12).

Достовірність об'єктивних показників до та після лікування становить $p=0,012$, суб'єктивних $-\mathrm{p}<0,05$.

Мінімальне значення різниці балів при об'єктивній оцінці становило 3 бали, при суб'єктивній 4, що виявляли при лікуванні тотальних та субтотальних рубцевих уражень. Найбільш часто показники знижувались на 5-8 балів як при об'єктивній оцінці, так і суб'єктивній.

Під час лабораторних досліджень встановлено, що у хворих з рубцевими десоормаціями визначався підвищений вміст лімфоцитів i еозинофрілів у периферичній крові. Дане підвищення по відношенню до показників здорових осіб становило 1,6 рази (p $<0,05)$ і 2,9 рази $(p<0,05)$ відповідно. Підвищення вмісту лімфоциитів і еозинофрілів у периферичній крові ми пов'язували з розвитком активної запальної реакції в зоні рубців, що підтверджувалося клінічними спостереженнями і суб'єктивними скаргами хворих (свербіж, біль, почервоніння рубців тощо). Застосування системи реабілітаційних заходів сприяло зниженню показників вмісту еозинофрілів на 79, $6 \%(p<0,05)$ і лімфроцитів на $21,61 \%(p<0,05)$ (табл. 1).

Водночас дані показники перевищували значення у здорових осіб. Дані тенденції свідчили про зниження розвитку лейкемоїдних і лімфоїдних реакцій у хворих даної групи, що, можливо, сприяло зниженню аутоімунних реакцій у пацієнтів з рубцевими десоормаціями.

Під час вивчення ступеня вираженості аутоімунних реакцій у хворих з післяопіковими рубцевими деформаціями нами встановлено, що цілісна аутологічна сироватка має виражену стимулюючу дію, сприяючи підвищенню активності лімфоцитів у даних реакціях (табл. 2).

Під час вивчення ролі різних фрракцій сироватки крові у підтриманні активності лімфоцитів 
в аутоімунних реакціях нами встановлено, що основну стимулюючу дію мала глобулінова фрракція сироватки крові. Так само встановлений фракт фріксації на поверхні еритроцитів аутоагресивних субстанцій, що підтверджувалося тестом 3 відмитими еритроцитами. При застосуванні запропонованої системи заходів реабілітації у хворих визначалась тенденція щодо зниження стимулюючої дії цільної аутологічної сироватки та ії̈ глобулінової фракції відносно вихідних показників на 33,4\% (p<0,05) та 49,1\% (p<0,05). Однак дані показники перевищували значення здорових осіб на 89,2 \% (p<0,05) та 75, $6 \%$ ( $<<0,05)$. Зазначена динаміка зміни показників активності лімфроцитів в аутоімунних реакціях дає підставу вважати, що незважаючи на очевидний позитивний ефект консервативних заходів у зниженні стимулюючої дії аутологічної сироватки та її глобулінової фрракції на показники активності лімфроцитів визначається досить високий рівень аутоімунних реакцій. Це свідчить про збереження аутосенсибілізації у даної категорії хворих на досить високому рівні.

Дане припущення підтверджується динамікою зміни показників вмісту ЦІК і кріоглобулінів (табл. 3).

Застосування лікувальних заходів ефективно знижує показники ЦІК і кріоглобулінів, однак вони значно перевищують значення здорових осіб і виявляють тенденцію до швидкого прогресивного росту в більш пізні терміни, що визначає необхідність повторних процедур.

У хворих в гострому періоді опікової хвороби відзначається розвиток ендотоксикозу 3 ушкодженням систем природної детоксикації [6]. Основна причина цих порушень - нагромадження молекул середньої маси (МСМ) і аутоагресивних сполук, що мають пряму ушкоджуючу дію. Гідрофробна фрракція МСМ знаходиться у плазмі крові практично цілком у зв'язаному стані у вигляді комплексів з альбумінами і ліпопротеінами низької щільності. Саме гідрофообні токсини (гідрофробні продукти деградації білка) мають найбільш значні токсичні властивості, оскільки дуже швидко зв'язуються 3 мембранами клітин крові і внутрішньоклітинними білками, змінюючи їхню структуру, підвищуючи проникність мембран та пригнічуючи ферментативну активність [1, 10-13].

Дані токсини значно впливають на функціональну активність лімфоцитів і моноцитів, що проявлялось розвитком декомпенсації фрункції й неспроможності фрагоцитуючих клітин сорормувати адекватну функціональну відповідь на мікробні антигени $[4,6]$.
ТАБЛИЦЯ 2 - Показники активності лімфоцитів в аутологічних реакціях у хворих з рубцевими деформаціями при застосуванні системи реабілітаційних заходів $(\mathbf{n}=18)$

\begin{tabular}{|l|c|c|c|}
\hline \multicolumn{1}{|c|}{ Показники } & $\begin{array}{c}\text { До } \\
\text { лікування }\end{array}$ & $\begin{array}{c}\text { Після } \\
\text { лікування }\end{array}$ & $\begin{array}{c}\text { Здорові } \\
\text { особи }\end{array}$ \\
\hline Спонтанна реакція, \% & $18,7 \pm 0,42^{*}$ & $12,2 \pm 0,3^{* *}$ & $1,7 \pm 0,9$ \\
\hline $\begin{array}{l}\text { Вплив аутологічної } \\
\text { сироватки, \% }\end{array}$ & $49,7 \pm 1,2^{*}$ & $37,3 \pm 0,9^{*},{ }^{* *}$ & $19,7 \pm 0,8$ \\
\hline $\begin{array}{l}\text { Вплив глобулінової } \\
\text { фракції сироватки, \% }\end{array}$ & $45,1 \pm 0,3^{*}$ & $30,2 \pm 0,9^{*},{ }^{* *}$ & $17,2 \pm 0,4$ \\
\hline $\begin{array}{l}\text { Вплив альбумінової } \\
\text { фракції сироватки, \% }\end{array}$ & $21,2 \pm 0,5^{*}$ & $17,2 \pm 0,7^{*},{ }^{* *}$ & $12,5 \pm 0,2$ \\
\hline $\begin{array}{l}\text { Вплив середнє та } \\
\text { низькорозмірних } \\
\text { вільних фрракцій, \% }\end{array}$ & $22,1 \pm 0,7^{*}$ & $12,5 \pm 0,5^{*},{ }^{* *}$ & $7,1 \pm 0,5$ \\
\hline Відмиті еритроцити, \% & $10,2 \pm 0,4^{*}$ & $6,3 \pm 0,3^{*},{ }^{* *}$ & $2,7 \pm 0,4$ \\
\hline
\end{tabular}

* $\mathrm{p}<0,5$ вірогідність відмінностей відносно показників здорових осіб; ** $\mathrm{p}<0,05$ вірогідність відмінностей відносно вихідних показників.

Відомо, що при опіковій хворобі виявляються суттєві порушення у гуморальній ланці імунітету у вигляді підвищених концентрацій імуноглобулінів, накопиченням ЦІК та кріоглобулінів у сироватці крові. ЦІК можуть фріксуватися на судинній стінці та на базальних мембранах у деяких внутрішніх органах і підтримувати запальну реакцію [10].

Накопичення аутоантитіл в організмі потерпілого з опіками призводить до патології СТ, що проявляється утворенням патологічних рубців, рубцевих деорормацій і контрактур [14-19]. Загальні і місцеві порушення, що виникають при утворенні патологічної тканини, свідчать про необхідність використання в лікуванні рубцевих десормацій патогенетично обумовленої еферентної терапії.

Виходячи $з$ даних клінічних і лабораторних досліджень, розроблені показники для проведення комплексної консервативної реабілітації хворим з післяопіковими рубцевими деформаціями:

- клінічні ознаки - печіння, свербіж, біль, парестезії, гіперемії в області рубців, які свідчать про розвиток активної запальної реакції;

- лабораторні ознаки розвитку аутоімунних реакцій - високі показники вмісту лімфроцитів і еозинофрілів у периферичній крові, високі зна-

ТАБЛИЦЯ 3 - Вміст циркулюючих імунних комплексів та криоглобулінів у хворих 3 рубцевими деформаціями при застосуванні програми лікування $(\mathrm{n}=18)$

\begin{tabular}{|l|c|c|c|}
\hline \multicolumn{1}{|c|}{ Показники } & $\begin{array}{c}\text { До } \\
\text { лікування }\end{array}$ & $\begin{array}{c}\text { Після } \\
\text { лікування }\end{array}$ & $\begin{array}{c}\text { Здорові } \\
\text { особи }\end{array}$ \\
\hline ЦІК, ум.од. & $0,43 \pm 0,2^{*}$ & $0,32 \pm 0,1^{*}$ & $0,14 \pm 0,1$ \\
\hline Кріоглобуліни, ум.од. & $72,3 \pm 3,2^{*}$ & $47,4 \pm 2,6^{* *}$ & 0 \\
\hline
\end{tabular}

* $p<0,05$ вірогідність відмінностей відносно показників здорових осіб; ** $p<0,05$ вірогідність відмінностей відносно вихідних показників. 
чення активності лімфоцитів в аутоімунних реакціях у присутності цільної аутологічної сироватки та глобулінової фракції, перевищення показників вмісту ЦІК і кріоглобулінів більш ніж в 2 рази.

\section{Висновки}

1. Система заходів консервативної реабілітації хворих з рубцевими ураженнями у перед та післяопераційні періоди реконструкції деформацій включає місцеві, медикаментозні, фрізіотерапевтичні, бальнеологічні засоби та методи еферентної терапії.

2. Позитивний вплив заходів досягається за рахунок зниження рівня вмісту аутоагресивних

\section{Література}

1. Auger C, Samadi O, Jeschke MG. The biochemical alterations underlying post-burn hypermetabolism. Biochimica et Biophysica Acta (BBA) Molecular Basis of Disease, 2017, 1863(10), 2633-2644. doi:10.1016/j.bbadis. 2017.02 .019

2. Жернов ОА, Козинець ГП, Жернов АО. Рубці шкіри як медична і соціальна проблема. [Skin scars as a medical and social issue]. Medix AntiAging. 2011, 20:58-60.

3. Lateef Z, Stuart G, Jones N, Mercer A, Fleming, S, Wise L. The Cutaneous Inflammatory Response to Thermal Burn Injury in a Murine Model. Int. J. Mol. Sci. 2019; 20: 538. https://doi.org/10.3390/ijms20030538

4. Van Lier D, Geven C, Leijte GP, \& Pickkers P. (2018). Experimental human endotoxemia as a model of systemic inflammation. Biochimie. 2019; 159: 99-106. doi:10.1016/j.biochi.2018.06.014

5. Finnerty CC, Jeschke MG, Branski LK, Barret JP, Dziewulski P, Herndon DN. Hypertrophic scarring: The greatest unmet challenge after burn injury. Lancet. 2016; 388: 1427-1436. doi: 10.1016/S0140-6736(16)31406-4.

6. Strudwick XL, Cowin AJ. The Role of the Inflammatory Response in Burn Injury. Hot Topics in Burn Injuries. Edited by Selda Pelin Kartal and Dilek Bayramgürler. 2018. doi:10.5772/intechopen.71330

7. Жернов ОА, Повстяний МЮ. Уніфікована класифікація контрактур після термічних уражень, Вісник наукових досліджень [Unified contracture classification after thermal damage]. Visnyk naukovykh doslidzhen'. 2003; 4(33): $34-37$

8. Жеров ОА, Стаскевич СВ, Осадча ОІ, Жернов АО. Корекція порушень гомеостазу у хворих 3 післяопіковими деформаціями 3 використанням еферентної терапії [Correcting homeostasis disorders in patients with post burn deformities using efferent therapy]. Український журнал гематології та трансфрузіології. 2012; 4(д): 437.

9. Жернов ОА, Осадча ОІ, Жернов АО, Назаренко ВМ, Стаскевич СВ. Лікування післяопікових та післяопераційних рубців із застосуванням препаратів Карипаїн та гель Карипаїн ультра [Treatment of post burn and postoperative scars by means of Carypain preparation and Carypain ultra gel]. Клінічна хірургія, 2011; 7: 60-4 фракторів, що відображується у сприятливому клінічному перебігу процесу. Однак разом із позитивним ефектом цього методу лікування нами відзначено збереження високої аутосенсибілізації у даній категорії хворих після проведення консервативних заходів, що вимагає проведення повторних процедур через 4-5 тиж.

3. Застосування системи заходів дозволяє своєчасно забезпечити сприятливі умови для компенсації загального стану реконвалесцентів та відновлення чи покращення порушених фрункцій уражених сегментів за об'єктивними оцінками у 1,75 раза і за оцінками пацієнтів - у 1,44 раза.

10. Шутурма ОЯ, Лісничук Н€, Довгалюк АІ. Циркулюючі імунні комплекси та їх роль у виникненні поєднаних патологій органів травної системи. [Circulating immune complexes and their role in occurrence of combined pathologies] Здобутки клінічної і експериментальної медицини. 2013; 2: 223-5.

11. Thangavel J, Samanta S, Rajasingh S, Barani B, Xuan Y-T, Dawn B, Rajasingh J. Epigenetic modifiers reduce inflammation and modulate macrophage phenotype during endotoxemia-induced acute lung injury. Journal of Cell Science. 2015; 128(16): 3094-3105. doi:10.1242/jcs.170258.

12. Mescher AL. Macrophages and fibroblasts during inflammation and tissue repair in models of organ regeneration. Regeneration. 2017; 6; 4(2): 39-53. doi: 10.1002/reg2.77.

13. Bainbridge P. Wound healing and the role of fibroblasts. Adv. Wound Care. 2013; 22(8): 407-12. DOI: 10.12968/jowc.2013.22.8.407

14. Zhu Z, Ding J, Ma Z, Iwashina T, Tredget EE. Systemic depletion of macrophages in the subacute phase of wound healing reduces hypertrophic scar formation. Wound Repair Regen. 2016; 24: 644-56. doi: 10.1111/wrr.12442

15. Wilgus TA, Wulff BC. The Importance of Mast Cells in Dermal Scarring. Adv. Wound Care. 2014; 3: 356-65. DOl: 10.1089/wound.2013.0457

16. Van De Water L, Varney S, Tomasek JJ. Mechanoregulation of the Myofibroblast in Wound Contraction, Scarring, and Fibrosis: Opportunities for New Therapeutic Intervention. Adv. Wound Care. 2013; 2: 122-41. DOI: 10.1089/wound.2012.0393

17. Chen L, Wang J, Li S, Yu Z, Liu B, Song, B, \& Su Y. The clinical dynamic changes of macrophage phenotype and function in different stages of human wound healing and hypertrophic scar formation. Int Wound J. 2019; 16 : 360-9. doi:10.1111/iwj.13041

18. Glaros T, Larsen M, Liwu L. Macrophages and fibroblasts during inflammation, tissue damage and organ injury. Frontiers in Bioscience. 2009; 14(10): 3988-93. DOI: $10.2735 / 3506$

19. Darby IA, Laverdet $B$, Bonté $F$, Desmoulière A. Fibroblasts and myofibroblasts in wound healing. Clin Cosmet Investig Dermatol. 2014; 6; 7: 301 11. doi: $10.2147 /$ CCID.S50046 